\title{
First record of Pycnoporellus albo-luteus in NW-Europe
}

\author{
Veikko Hintikka
}

In August 1967 when collecting with Mr. Kari Korhonen I found Pycnoporellus alboluteus (Ell. \& Ev.) Kotl. \& Pouz. (Hapalopilus alboluteus (Ell. \& Ev.) Bond. \& Sing.) in the Rovaniemi commune of northern Finland $\left(66^{\circ} 21^{\prime} \mathrm{N}\right)$. This rare species was growing in the Kivalo Experimental Forest in an old spruce forest with a thick moss layer (Hylocomium - Myrtillus type) on the southern slope of Hyypiönkivalo hill near the Hyypiön kämppä loggers cabin, where scattered spruces had been cut about 15 years ago, the heart-rotted basal trunks of the spruce trees being left in the forest. On the cut surface of one such trunk Pycnoporellus was growing abundantly (Fig. 1). The spe- cies is easily recognized by its very large pores and by its context, which becomes deep-red in $\mathrm{KOH}$. The determination was kindly confirmed by Dr. F. Kotlaba, Prague.

Pycnoporellus albo-luteus has not been previously recorded in the Nordic countries (Ryvarden 1968). The nearest occurrences are in the Bialowieza forest in Poland (DoMANSKI 1965) and in the eastern parts of the mountains of Central Europe (BondARTSEV 1953). The main area of distribution seems to be in North America, where the species occurs in particular on the logs of coniferous trees in the subalpine zone, mainly from the Rocky Mountains westwards (Overholts 1953).

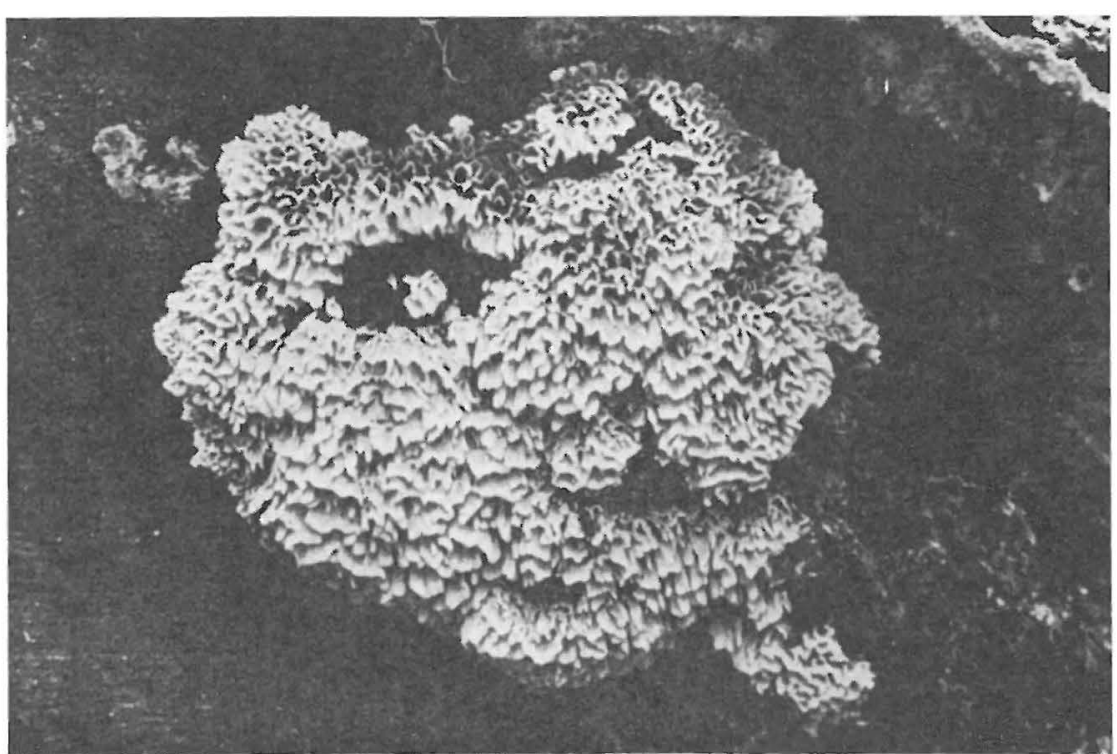

Fif. 1. Pycnoporellus albo-luteus on a spruce log in Rovaniemi, northern Finland. Photo Kari KorHONEN. 


\section{REFERENCES}

Bondartsev, A. S., 1953: Trutovye griby evropeiskoi chasti SSSR i Kavkaza. - 1106 pp. Moskva.

Domanski, S., 1965: Grzyby (Fungi). Flora Polska. - 279 pp. + 63 Tab. Warzawa.

Overholts, L. O., 1953: The Polyporaceae of the
United States, Alaska and Canada. Prepared for publication by J. L. Lowe. 466 pp. Ann Arbor.

Ryvarden, L., 1968: Flora over kjuker. - 96 pp. Oslo. 